\title{
Exotic tree Artocarpus heterophyllus (Moraceae) invades the Brazilian Atlantic Rainforest
}

\author{
Árvore exótica Artocarpus heterophyllus (Moraceae) invade a Mata Atlântica brasileira
}

Rodolfo Cesar Real de Abreu ${ }^{1,2}$ \& Pablo José Francisco Pena Rodrigues ${ }^{1}$

\begin{abstract}
Artocarpus heterophyllus Lam. (jackfruit) was man made introduced in Tijuca National Park (TNP) in the mid1800s. Native from Southeast Asia, nowadays densely colonizes the TNP. Here we analyze some jackfruit population parameters that probably allowed the local colonization followed by successful invasion of the new habitat. Based on 20 sample plots, randomly placed inside 5 sites colonized by jackfruit, we described subpopulations hierarchical size diameter structures. Gini's coefficient values turned around 0.64 and Lorenz's asymmetry coefficient around 1.03 , indicating that size hierarchies were very similar between sites. The five sites were also compared and do not differ based on jackfruit basal area, number of species, Shannon's index and canopy openness. Jackfruit may, therefore, be considered invasive in all these sites and the low tree diversity values ( $\mathrm{H}^{\prime}$ overall mean 0.74 ) also indicates that this exotic species locally excludes native ones.

Keywords: jackfruit, invasive species, biological invasion, population structure, Tijuca National Park, Brazil.

\section{Resumo}

Artocarpus heterophyllus Lam. (Jaqueira) foi introduzida pelo homem no Parque Nacional da Tijuca (PNT), em meados do século XVIII. Nativa do sudeste da Ásia, esta espécie exótica hoje coloniza densamente o PNT. Neste estudo analisamos alguns parâmetros populacionais da jaqueira que provavelmente permitiram a colonização local e conseqüentemente a invasão bem sucedida deste novo habitat. A partir da amostragem de 20 parcelas alocadas aleatoriamente em cinco sítios colonizados por jaqueiras, descrevemos as estruturas de diâmetro das subpopulações. Os coeficientes de Gini oscilaram em torno 0,64 e os de Lorenz 1,03, indicando hierarquia de tamanhos semelhante entre as amostras. Os cinco sítios também foram comparados e não diferiram quanto à área basal de jaqueiras, riqueza total de espécies, índice de diversidade de Shannon e abertura do dossel. A jaqueira pode, portanto, ser considerada invasora em todos estes sítios e os baixos valores de diversidade de árvores ( $\mathrm{H}^{\prime}$ em torno de 0,74$)$ também podem indicar que esta espécie exótica exclui localmente as espécies nativas.

Palavras-chave: jaqueiras, espécies invasoras, invasão biológica, estrutura de populações, Parque Nacional da Tijuca, Brasil.
\end{abstract}

\section{Introduction}

Human-mediated changes in natural ecosystems have caused profound biota modifications, and prominent changes in geographic distributions of plants and animals (Cronk \& Fuller 1995; Williamson 1996; Pimentel et al. 2001). Species naturally cross geographical barriers, but human activities such as international commerce and intercontinental travel have strongly contributed to accelerate these transpositions (Richardson et al. 2000; Pimentel et al. 2001). Artificial introductions can be extremely harmful to local ecosystems, causing negative and even unrecognized impacts (Williamson 1996). Mainly because some exotic species are able to change local ecosystem functioning (Kourtev et al. 1999; Zavaleta et al. 2001) and biodiversity patterns (Stohlgren et al. 2001).

Invasive exotic species (IES) also may cause native species extinctions, in some cases comparable to geological mass-extinctions (Cassey et al. 2005),

\footnotetext{
${ }^{1}$ Instituto de Pesquisas Jardim Botânico do Rio de Janeiro, R. Pacheco Leão 915, 22460-030, Rio de Janeiro, RJ, Brasil. Autor para correspondência: pablo@jbrj.gov.br
} ${ }^{2}$ Current adress: PPG-SEA - Centro de Recursos Hídricos e Ecologia Aplicada CRHEA/EESC/USP. Av. Trabalhador São Carlense 400, 13566-590, São Carlos, SP. 
leading to biota homogenization (McKinney \& Lockwood 1999). World's biodiversity reduction is straightly related to habitat loss and invasion (Simberloff 2003), both impacts fully experienced by Brazilian ecosystems (e.g., Pivello et al. 1999; Scariot 2001). However, the magnitude of the problems generated by biological invasions will vary depending on the exotic species introduced, on the length of time since its introduction and the susceptibility of the environment to invasion (Williamson 1996).

In Brazil, only a few studies describe IES biology in new habitats, especially trees. Mostly invasion process detection only occurs after high dominance of the invader or another advanced impact on local community can be recognized (Williamson 1996). Since an exotic species is detected colonizing natural habitats, population structure may reveal the capacity of population expanding at present, once this structure can indicate demographic future of species (Bruna \& Kress 2002). In this aspect, ancillary tools that describe the degree of inequality in structured populations have been widely used in the description of hierarchies of sizes within populations (Weiner \& Solbrig 1984; Solbrig \& Solbrig 1984). Among these, we highlight the Gini's coefficient and the Lorenz's curve. Gini's coefficient has been used in biological studies generally to describe size hierarchies and/or intraspecific competition of annual plants (Weiner 1985, 1986; Damgaard \& Weiner 2000), system crops (Sadras \& Bongiovanni 2004) and tree populations on natural habitats (Rouvinen \& Kuuluvainen 2005; Bagchi 2007). On the other hand, the Lorenz curve can be a better descriptor than skewness, generally used to describe population structures (Weiner \& Solbrig 1984; Damgaard \& Weiner 2000). Furthermore, a population's stage structure can be the basis for immediate management decisions (Bruna \& Kress 2002), specially related to invasive species with long life cycles and increasing populations.

The jackfruit Artocarpus heterophyllus Lam. (Moraceae) is an exotic species native from Southeast Asia, which now occurs widely in reserves of the Atlantic Forest in Rio de Janeiro, Brazilian Southeast. Probably the introduction of jackfruit trees into some areas of the lowest part and the middle slopes of the Tijuca National Park (TNP) began in 1862 with a reforestation program, in which both native and exotic species were simultaneously introduced (Atala et al. 1966; Bandeira 1993; Dean 2002). This program was the first Brazilian initiative to recover a forest ecosystem previously devastated by sugarcane and coffee cycles (Conti et al. 2008). But the widespread information that the whole TNP (4.000 ha) was recovered by that restoration initiative it is not true. Environmental history data of Rio de Janeiro Atlantic forest showed that these reforestation was responsible by 100,000 seedlings planted, covering 170 ha (Oliveira 2007). In fact remaining forest fragments, on higher areas of the Tijuca forest, probably could act as propagule sources colonizing the deforested areas and also enriching the restored sites. Nowadays, in some areas at TNP A. heterophyllus is dominant in density and biomass (Abreu \& Rodrigues 2005, Cunha et al. 2006). These populations may have originated from some individuals that were historically introduced in the above-mentioned reforestation, from which the exotic species has reached the status of invasive, since it appears to have expanded naturally.

Furthermore, we compared the population size structures of the invasive tree $A$. heterophyllus in five sites of TNP. Specifically, we tested the following two predictions: (1) population size structures change among sites, suggesting that some sites are more invasible than others; (2) diversity indexes decrease in places occupied by jackfruits. In testing these hypotheses, our goal is to determine which places of TNP suffered major impacts due to biological invasion, and to set priority sites to management and control of this invasive species.

\section{Material and Methods}

\section{Study area}

Tijuca National Park (TNP) is one of the largest urban forests in the world, and is widely

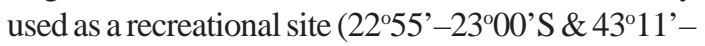
4319'W). Three fragments constitute TNP, subdivided by four sectors with 4.000 ha altogether inside Tijuca Massif, compound by innumerous mountains that reaches until 1021 a.s.l. (IBAMA 2004) situated at the Brazilian second-largest economic and populational center (IBGE 2006). This fact may cause impacts such as uncontrolled urban growth in the boundary regions (Coelho-Netto et al. 2007), atmospheric pollution (Azevedo et al. 1999) and the presence of non-native fauna (Cunha et al. 2006) and flora (Bandeira 1993). 
The annual precipitation varies from 1300 mm to slightly more than $3000 \mathrm{~mm}$, with abundant precipitation also in winter (Mattos et al. 1970) and torrential rains in the hot summer months (December-February) (Coelho-Netto et al. 2007). Lithosols, cambisols and latosols predominate in the upper part, and podzolic soils in the lower part (Coelho-Netto et al. 2007).

The TNP vegetation is typical of tropical rain forests, characterized by big trees, palms, ferns, epiphytes, and lianas. In the mature forest, emergent trees reach $25 \mathrm{~m}$ height and canopy strata mean height is about $20 \mathrm{~m}$ (Atala et al. 1966). Within the $\mathrm{TNP}$, there is a mosaic of vegetation ranging from undisturbed forests to patches totally invaded by African grasses. Notwithstanding, the most representative families in that study were Myrtaceae, Lauraceae, Leguminosae, Rubiaceae, Euphorbiaceae, Meliaceae and Annonaceae. The more representative species were Coussarea nodosa (Benth.) Müll. Arg., Geonoma schottiana Mart., Myrcia rostrata DC., Myrcia laxiflora Cambess., Allophylus edulis (A. St.-Hil., Cambess. \& A. Juss.) Radlk., Cryptocarya moschata Nees \& C. Mart., Tetrorchidium aff. rubrivenium Poepp., Eugenia prasina O. Berg, Pausandra megalophylla Müll. Arg. and Trigynaea sp. Schltdl. (Oliveira et al. 1995).

\section{The studied species}

Artocarpus heterophyllus Lam. is a species originated from Southeast Asia (Chaves et al. 1967). In the year 1682, in the state of Bahia, there were already 11 jackfruit trees of unknown origin. The first record of a shipment to Brazil dates from January 1683 (Ferrão 1993). The recently arrived seeds and seedlings were sent to a nursery in Bahia State to be acclimated, and were later distributed to other regions of the country (Dean 2002). In 1803 in Rio de Janeiro municipality, naturalized adult individuals apparently already existed (Chaves et al. 1967).

The jackfruit is a large tree, reaching a height of more than 10 meters; the trunk may exceed 1 meter in diameter. It is monoecious and cauliflorous (Chaves et al. 1967; Crane et al. 2002). The species can be pollinated by insects or wind, tolerates climate stresses well, and in ideal orchard conditions it can fruit in three or four years (Crane et al. 2002). In Brazil, a well-developed jackfruit tree can produce up to 100 fruits per year, some weighing more than $30 \mathrm{~kg}$ (Chaves et al. 1967). Individuals of this species fruit asynchronously during the entire year, with a large proportion preferentially fruiting in summer (December-February). The fruits are consumed by humans and by other mammals such as rodents and primates (Cunha et al. 2006). Field observations indicated a high germination rate of seeds in edge areas or where the species already occurred (R.R. Oliveira, personal communication). Presently, its distribution includes nearly the entire territory of Brazil in a fairly wide range of habitats, colonizing open and forested areas associated with humanimpacted environments (Carauta \& Diaz 2002). In Rio de Janeiro, it densely colonizes edge areas of the Atlantic Forest, and is found in Reserves such as the Tijuca National Park and the Poço das Antas, União and Tinguá biological reserves (Abreu \& Rodrigues 2005).

On the native habitat (Southeast Asia), A. heterophyllus is typical of advanced successional stages, and grows naturally up to an altitude of 1300 $\mathrm{m}$ in the sub-canopy of the Monodominant Humid Tropical Forest. The species is considered rare (up to 1 individual per ha) in this environment, where few species dominate the different forest strata (Chittibabu \& Parthasarathy 2000; Bhuyan et al. 2003). It is shade-tolerant, and germinates best in clearings; the fruits mature between July and August, and the seeds vary in size and weight (1.5 to $14 \mathrm{~g}$ ). Their dispersers include rodents, monkeys and wild pigs (Khan 2004). The seeds have a relatively high rate of predation (Sodhi et al. 2003) and germinate in the rainy season, during the summer (May-September) when $85 \%$ of the annual precipitation occurs (Chittibabu \& Parthasarathy 2000; Bhuyan et al. 2003). In this manner, the seeds germinate and the seedlings establish themselves, becoming able to easily tolerate the December-February dry season (Chittibabu \& Parthasarathy 2000; Bhuyan et al. 2003).

\section{Sites descriptions}

Five study sites were sampled at TNP. They have similar disturbance histories, because comprised areas which were at one time deforested for sugarcane and/or coffee cultivation, and where the jackfruit trees were later introduced and naturally disseminated. Random sampling methods were used to demarcate plot locations at each site (Mueller-Dumbois \& Ellenberg 1974).

Site 1 - Located in the "A" sector of TNP, a fragment with approximately 1,300 ha. This site is locally known as "Represa dos Ciganos". Six plots were 
placed at Northern exposed slopes. This fragment has a well structured forest with tall trees and there were the tallest jackfruit trees.

Site 2 - Locally known as "Horto Florestal”, that site belongs to the " $\mathrm{B}$ " sector of TNP, the bigger fragment with approximately 1,660 ha. Two plots were placed close to the well preserved forest remnant known as “Mata do Pai Ricardo”, located at Southern slope near a boundary region. At that place, jackfruit densely colonized roadsides and it is believed that jackfruit root systems can prevent sliding of slopes.

Site 3 - This site is located in the "C" sector, which is a forest fragment with high hills, covering about 230 ha. Site 3 comprises four plots placed on the Southern slopes. Two from these plots were placed in the riparian area.

Site 4 - It is also located in the "C" sector, but plots were established on the Northern slopes.

Site 5-This site is locally known as "Parque Lage", which was a sugar cane and coffee farm in the past, at present covered by secondary forest and planted trees. Since 2004 it was embedded to the "B" sector of TNP. The vegetation structure is very similar to the other areas of TNP but exotic species occur at the bottom regions. Four plots were located close to a trackside used by park visitors (track to “Corcovado”), exposed to Southern direction.

\section{Structures of trunk diameters}

In the year 2004, 20 circular permanent plots (10 $\mathrm{m}$ radius; $314 \mathrm{~m}^{2}$ each) were set to survey jackfruit populations at TNP. The 20 plots were distributed in five sites scattered throughout TNP, where jackfruit populations were recorded.

All individuals of the plant community with a diameter at breast height $(\mathrm{DBH}) \geq 5 \mathrm{~cm}$ were then marked and measured. In the year 2009, all those individuals were again measured and individuals with $\mathrm{DBH} \geq 1 \mathrm{~cm}$ were included in the survey. To calculate individual basal areas (BA) we used the formula: $S=\pi . r^{2}$; where: $S=$ individual basal area (circle area); $\pi=3.14$ and $r=$ radius (radius $=$ half of the DBH measured). Individuals with visibly interlinked multiple trunks were considered as a single individual; in these cases, each trunk was measured separately and their BA were summed, and from the resulting basal area a single virtual diameter $>1 \mathrm{~cm}$ was obtained.

The basal areas of all individuals were calculated from the DBHs. One-Way ANOVAs followed by an a posteriori Tukey's test (HSD for unequal Ns; $\mathrm{p}<0.05)$ were used to assess whether the parameters analyzed (number of individuals, total basal area, basal area of jackfruits) differed significantly among sites, because any difference found may be indicative of different processes and patterns experienced by each subpopulation. The site 2 was not considered due to small number of replicates (2).

To test the hypothesis that (1) population size structure change among sites, suggesting that some sites are more severely invaded than others, we performed trunk diameters structure from the five sites and made comparisons between than through frequency distributions, measures for size inequalities in population structure, and spatial distribution at plot scales.

Attempts to confirm the age of these individuals by their wood anatomy were unsuccessful, since this species does not form growth rings.

\section{Frequency distribution}

Diameter classes were established according to morphological characters observed in the field during the pilot study to define ontogenetic stages (e.g., presence of reproductive structures and characteristics of the crown and/or trunk). A frequency histogram were developed, where the class JUVENILES 1 was composed of small sized trees with DBH ranging from 1 to $4.9 \mathrm{~cm}$; JUVENILES 2 was composed of small- to medium-sized trees with DBH ranging from 5 to $9.9 \mathrm{~cm}$ and the crown little developed. The individuals of class JUVENILES 3 included small to medium trees with DBH ranging from 10 to $14.9 \mathrm{~cm}$, still with the crown relatively little developed. The class of PRE-REPRODUCTIVES included individuals from 15 to $24.9 \mathrm{~cm} \mathrm{DBH}$, composed of large immature (non-reproductive) trees, with a relatively full crown. The reproductive individuals were divided into the classes ADULTS 1 and 2. The class ADULTS 1 included trees with DBH from 25 to $44.9 \mathrm{~cm}$, with a smooth trunk. The class ADULTS 2 included individuals with a diameter equal or greater than $45 \mathrm{~cm}$, generally with bark fissures on the trunk.

\section{Population inequality measures}

Size inequality was assessed using Lorenz's curves, Gini's coefficient (Weiner \& Solbrig 1984), Lorenz's asymmetry coefficient (Damgaard \& Weiner 2000) and their respective confidence intervals. In the Lorenz's curve, individuals were ranked according to their size (DBH in this case) 


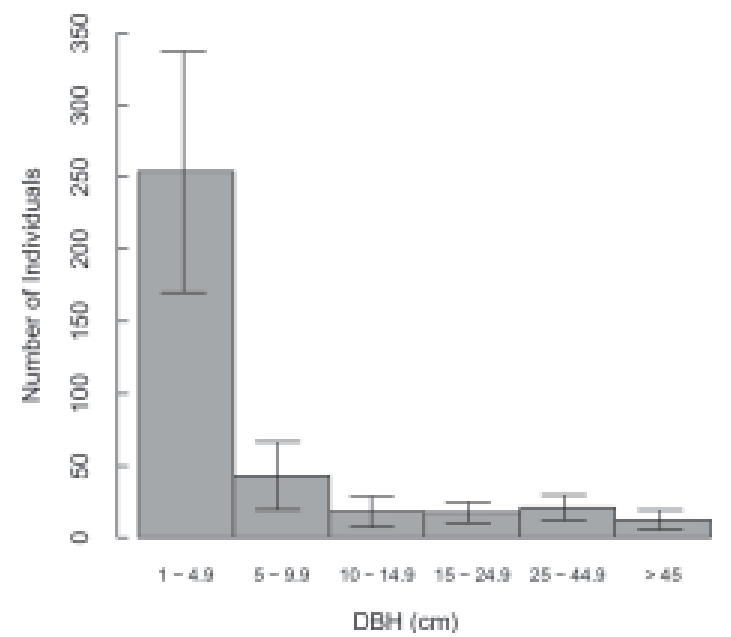

Figure 1 - Diameter histogram of jackfruit subpopulations at Tijuca National Park, Rio de Janeiro, in 2009 (DBH $\geq$ $1 \mathrm{~cm})$. The vertical lines indicate one standard deviation for each class.

and cumulative fraction of the population size was plotted against cumulative fraction of total population size. If individuals contribute to overall population size in proportion to their own size, then a straight line of equality is expected. Hierarchy degree can be summarized by Gini's coefficient represented by the difference between equality line and Lorenz's curve (Solbrig \& Solbrig 1984; Damgaard \& Weiner 2000). Gini's coefficients calculated should be multiplied with $n /(n-1)$ to the estimates become unbiased (Weiner 1985). Lorenz's asymmetry coefficient (S) expresses internal asymmetry from Lorenz's curve to the axis of symmetry. $S$ values from 1 indicates a symmetrical Lorenz's curve, $\mathbf{S}<1$ indicates asymmetry to the left and $\mathrm{S}>1$ right asymmetry (Damgaard \& Weiner 2000). Confidence intervals ( $\mathrm{p}=0.05$ ) for the estimates of $G$ and $S$ for a sample were obtained with 1,000 repetitions in a bootstrapping procedure (see Dixon et. al 1987). To $\mathrm{G}$ calculations and comparisons between sites we used WINGINI 1.0 (Santos 1996). To S calculations and confidence intervals we used a trial version from MATHEMATICA 7.0 with a notebook developed by Daamgard \& Weiner (2000).

\section{Spatial distribution}

The spatial distribution pattern was determined using Morisita's index. To calculate this index all 20 sample plots were considered. As observed by Souza \& Martins (2002), the Morisita Index $\left(\mathrm{I}_{\mathrm{m}}\right)$ gives the type of spatial distribution, indicated by the values: $I_{m}=1$ random distribution,
$I_{m}>1$ aggregated distribution, and $I_{m}<1$ uniform distribution, and a measurement of the degree of aggregation, whereas other measurements of dispersion test only one of these patterns. This index has desirable statistical properties: it has a known sampling distribution, and is not influenced by sample size. To test the significance of the values of $\mathrm{I}_{\mathrm{m}}$ of 1.0 , the chi-square test was used: $\chi^{2}(\mathrm{df}=\mathrm{Q}-1)=(\mathrm{Q}-1) s^{2} / \mu$ (Souza \& Martins 2002 apud David \& Moore 1954), where Q is the total number of plots, and $s^{2}$ and $\mu$ are, respectively, the variance and mean of the number of jackfruit trees per plot.

\section{Richness, biodiversity} and canopy structure

Community sampled trees were classified in morphospecies. From these data, PC-ORD 5.19 (McCune \& Mefford 1999) was used to calculate richness and Shannon-Weiner biodiversity index in every plot.

To describe canopy structure, we calculate canopy openness after taking digital pictures with a Nikon Coolpix 990, a fisheye lens (Nikon FC-08) and a tripod one meter high. Pictures were taken according to terrain slope in the center of plots during cloudy homogeneous skies from 2007 summer. To analyze pictures we used WINSCANOPY 2003.d in an automatic threshold manner (Regent 2003).

Comparisons among sites were done after normality tests. Since variables do not fit to normal distribution, Kruskal-Wallis tests were applied. Site 2 was not included in the analyses due to small number of replicates (2).

\section{Comparisons with native species}

In order to detect population patterns of native species to compare to the populations of jackfruits, secondary data from phytossociological samples in areas of the Atlantic Forest were used, in which only those species with the highest values of basal area were selected.

\section{Results}

Within the plots, the subpopulations contained high relative densities of jackfruits, ranging from $40 \%$ to $100 \%$ of the individuals in a locality. A total of 1262 JUVENILES 1 (DBH 1 to $4.9 \mathrm{~cm}$ ) and 564 bigger trees (DBH $>5 \mathrm{~cm}$ ) were sampled in 2009, and the mean basal area of jackfruits was $1.712 \pm 0.773 \mathrm{~m}^{2}$ plot $^{-1}$, with approximately $28 \pm 11$ trees plot $^{-1}$ (Tab. 1 ). 
The structure of the jackfruit population in TNP in 2009 (diameters histogram) showed the rightasymmetrical log-linear distribution pattern,

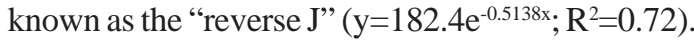
The largest proportion of the individuals (70\%) were in the first size class, and the classes of reproductive adults corresponded to $9 \%$ of the individuals of the population.

The densest subpopulations contained many immature and few adults. However, as expected, adults were responsible for the greater proportion of the basal area, which were distributed unequally between adults and immatures (Tab. 2).

Maximum DBH ranged from 80.9 in site 1 to 108.7 in site 3. Gini's coefficients were all near 0.65 and Lorenz's asymmetry coefficients were all near 1 (Tab. 3). These values indicate high similarity in size hierarchies and no sample asymmetry were observed between smaller and bigger individuals in a single site. No differences were observed between sites. Analyzing the confidence intervals of the coefficients, all sites had the same size hierarchies. In the landscape scale, Artocarpus heterophyllus showed clumped patterns, resulting in a Morisita's Dispersion Index value of 1.11.

The sites were also very similar in terms of basal area (BA), richness (S), Shannon-Wiener diversity index (H') and canopy openness (Tab. 4). Mean basal areas were about $1.71( \pm 0.77) \mathrm{m}^{2} \mathrm{plot}^{-1}$, mean richness was $6( \pm 4)$ species plot ${ }^{-1}, H^{\prime}$ was about 0.74 and mean canopy openness was $6.16 \%$.

Comparing the basal area (BA) of the subpopulations of $A$. heterophyllus with the BA of other species of the Atlantic Forest (Tab. 5), the BA occupied by jackfruits was 10.9 to 98.1 times larger than the BA of native tree species of the Atlantic Forest.

\section{Discussion}

Although exotic species may be rare in undisturbed tropical forests, in disturbed forests such species may become invasive and even cause drastic changes to the ecosystem, including indirect habitat destruction, facilitating their own dominance over the native species (Fine 2002). Jackfruit nowadays densely colonizes many sites at Tijuca National Park (TNP), an urban and permanently disturbed forest remnant. In addition, impacts on natural habitats, such as fragmentation and habitat loss, may favor the dissemination of this exotic species (Davis et al. 2000; Fine 2002). In this way, the successful man-mediated introduction of jackfruits into the TNP (Atala et al. 1966; Bandeira 1993) after 150 years resulted in an effective habitat invasion that probably represents the most massive invasion promoted by a tree species at Atlantic Rainforest.

Other Brazilian Reserves that have edge sites colonized by jackfruit showed an increased basal area when compared to other edge sites (Rodrigues 2004). This fact may indicate that even populations of native species with larger basal areas in local communities are incapable to colonize the locality in the same manner as the jackfruits. The jackfruit colonization success as well as the dominance in density and biomass (Abreu \& Rodrigues 2005; Cunha et al. 2006) can be also favored by population patterns such as clumped distribution, dispersal way (barochory), and by the probably escape from natural enemies (Sax \& Brown 2000; Keane \& Crawley 2002). The time elapsed since the introduction of the species by planting in a locality may also contribute for species dissemination (Williamson 1996). Furthermore, the jackfruit seed predation rate is high in preserved areas and low in forest edges, and in the latter areas the species shows a high germination (R.R. Oliveira, personal communication). In a pilot study (unpublished data) we observed single plots $\left(2 \mathrm{~m}^{2}\right)$ having more than 200 jackfruit seedlings. This shows that the jackfruit can regenerate better than other species from the Atlantic Rainforest. And it can be explained because in tropical forests, plants with larger seeds tend to germinate more readily than plants with small seeds (Dawson et al. 2009).

Table 1 - Summary of parameters used to characterize the plant community structure in the plots studied in Tijuca National Park in $2009(\mathrm{DBH} \geq 1 \mathrm{~cm}) . \mathrm{BA}_{\text {total }}=$ entire community $\left(\mathrm{m}^{2}\right.$ ha $\left.{ }^{-1}\right)$ basal area; $\mathrm{BA}_{\text {jaq }}=$ basal area composed exclusively of jackfruit in the community $\left(\mathrm{m}^{2}\right.$ ha $\left.{ }^{-1}\right) ; \mathrm{BA}_{\text {others }}=$ basal area occupied by other individuals, not jackfruits $\left(\mathrm{m}^{2} \mathrm{ha}^{-1}\right) ; \mathrm{N}_{\text {total }}=$ number of individuals in the community (trees.ha $\left.{ }^{-1}\right) ; \mathrm{N}_{\text {jaq }}=$ number of jackfruit individuals in the community (trees ha ${ }^{-1}$ ). Mean $\pm \mathrm{SD}=$ mean and standard deviation of parameters by plot $\left(314 \mathrm{~m}^{2}\right)$.

\begin{tabular}{|c|c|c|c|c|c|}
\hline & $B A_{\text {total }}\left(m^{2} h^{-1}\right)$ & $\mathbf{B A} A_{\mathrm{jaq}}\left(\mathrm{m}^{2} h^{-1}\right)$ & BA others $\left(\mathrm{m}^{2} \mathrm{ha}^{-1}\right)$ & $\mathbf{N}_{\text {total }}\left(\right.$ trees ha $\left.\mathbf{h}^{-1}\right)$ & $\mathbf{N}_{\text {jaq }}($ trees ha-1) \\
\hline Total & 68.446 & 54.351 & 15.916 & 1107 & 889 \\
\hline Mean \pm SD & $2.149 \pm 0.787$ & $1.649 \pm 0.762$ & $0.952 \pm 2.115$ & $34.75 \pm 9.5$ & $27.9 \pm 11.5$ \\
\hline
\end{tabular}


Table 2-Jackfruit demographic patterns of the study sites (mean \pm standard deviation). Sites=localities (number of sites in the locality, see methods text); Immatures = individuals with DBH ranging from 5 to $24.9 \mathrm{~cm}$; Adults = individuals with DBH greater than $25 \mathrm{~cm}$; $\mathrm{n}=$ number of individuals; $\% \mathrm{n}=$ percentage of number of individuals; $\mathrm{BA}=$ basal area; $\% \mathrm{BA}=$ percentage of basal area; ANOVA $=$ values of MS for One-Way ANOVAs, $\mathrm{df}=15, \mathrm{p}<0.05$, Tukey's test for unequal Ns. Symbol $(*)$ indicates that no significant differences were observed.

\begin{tabular}{lcccccccc}
\hline \multicolumn{3}{c}{ Immatures } & \multicolumn{3}{c}{ Adults } \\
\hline Sites & $\mathrm{n}$ & $\% \mathrm{n}$ & $\mathrm{BA}$ & $\% \mathrm{BA}$ & $\mathrm{n}$ & $\% \mathrm{n}$ & $\mathrm{BA}$ & $\% \mathrm{BA}$ \\
\hline $1(6)$ & $23 \pm 10$ & 71 & $0.28 \pm 0.14$ & 17 & $10 \pm 6$ & 29 & $1.38 \pm 0.82$ & 83 \\
$2(2)$ & $25 \pm 13$ & 79 & $0.34 \pm 0.19$ & 19 & $7 \pm 1$ & 21 & $1.47 \pm 0.25$ & 81 \\
$3(4)$ & $16 \pm 7$ & 73 & $0.16 \pm 0.07$ & 10 & $6 \pm 1$ & 27 & $1.47 \pm 1.07$ & 90 \\
$4(4)$ & $15 \pm 5$ & 61 & $0.19 \pm 0.11$ & 13 & $9 \pm 5$ & 39 & $1.27 \pm 0.72$ & 87 \\
$5(4)$ & $22 \pm 11$ & 73 & $0.22 \pm 0.10$ & 12 & $8 \pm 3$ & 27 & $1.53 \pm 0.62$ & 88 \\
ANOVA* & 82.889 & & 0.01498 & & 17.167 & & 0.63681 & \\
\hline
\end{tabular}

Table 3 - Parameters analyzed to describe the structure hierarchy of sizes (DBH) in the sites studied in the Tijuca National Park, $\mathrm{RJ}(2009)$. Site $=$ studied site; $\mathrm{n}=$ number of individuals; mean $\pm \mathrm{SD}=$ mean and standard deviation of DBH; $\max \mathrm{DBH}=$ greaterDBH observed in the site; $\mathrm{G}^{\prime}=$ corrected Gini's coefficient; $\mathrm{CI}$ G' 95\% = confidence interval for G'; $\mathrm{S}$ = Lorenz' Asymmetric Coefficient; CI S $95 \%=$ confidence interval for S.

\begin{tabular}{cccccccc}
\hline Site & $\mathbf{n}$ & \multicolumn{1}{c}{ DBH } & max DBH & \multicolumn{1}{c}{ G' } & \multicolumn{1}{c}{ CI G' 95\% } & \multicolumn{1}{c}{ S } & \multicolumn{1}{c}{ CI S 95\% } \\
\hline $\mathbf{1}$ & 723 & $6.77 \pm 11.42$ & 80.9 & 0.6452 & {$[0.6232-0.6615]$} & 1.0346 & {$[1.0006-1.0794]$} \\
$\mathbf{2}$ & 196 & $7.80 \pm 13.07$ & 81.9 & 0.6481 & {$[0.5931-0.6815]$} & 1.0375 & {$[0.9497-1.0977]$} \\
$\mathbf{3}$ & 205 & $10.41 \pm 17.39$ & 108.7 & 0.6467 & {$[0.5891-0.6780]$} & 1.094 & {$[0.9890-1.1470]$} \\
$\mathbf{4}$ & 298 & $9.15 \pm 10.03$ & 83.6 & 0.6551 & {$[0.6328-0.6736]$} & 0.9682 & {$[0.9050-1.0304]$} \\
$\mathbf{5}$ & 404 & $7.46 \pm 13.51$ & 107.7 & 0.6459 & {$[0.6061-0.6753]$} & 1.0317 & {$[0.9843-1.0954]$} \\
\hline
\end{tabular}

Table 4-Means $( \pm$ SD) from parameters used in the comparisons between the sites. DBH $1=$ Basal area composed of jackfruits with $\mathrm{DBH} \geq 1 \mathrm{~cm} ; \mathrm{DBH} 10=$ Basal area composed of jackfruits with $\mathrm{DBH} \geq 10 \mathrm{~cm} ; \mathrm{S}=$ species richness; $\mathrm{H}=$ Shannon-Weiner biodiversity index; Openness = canopy openness (\%). No significant differences were observed between sites.

\begin{tabular}{cccccc}
\hline Site & DBH 1 & DBH 10 & S & H & Openness \\
\hline $\mathbf{1}$ & $1.67 \pm 0.99$ & $1.58 \pm 0.97$ & $4.33 \pm 2.07$ & $0.53 \pm 0.45$ & $5.64 \pm 0.48$ \\
$\mathbf{2}$ & $1.78 \pm 0.00$ & $1.70 \pm 0.02$ & $6.00 \pm 1.41$ & $0.72 \pm 0.44$ & $5.88 \pm 0.35$ \\
$\mathbf{3}$ & $1.65 \pm 0.90$ & $1.59 \pm 0.86$ & $4.25 \pm 3.59$ & $0.75 \pm 0.80$ & $6.16 \pm 0.34$ \\
$\mathbf{4}$ & $1.64 \pm 0.88$ & $1.59 \pm 0.87$ & $9.75 \pm 6.24$ & $1.18 \pm 0.92$ & $7.66 \pm 1.33$ \\
$\mathbf{5}$ & $1.89 \pm 0.72$ & $1.80 \pm 0.70$ & $5.25 \pm 1.71$ & $0.62 \pm 0.05$ & $5.60 \pm 0.70$ \\
\hline
\end{tabular}

Ecosystems invasibility must not be generalized, because they are closely dependent on scale, vegetation type, biome, and resources availability (Stohlgren et al. 1999). Furthermore, in some cases it is not necessary to the invader to be aggressive when this species arrived to occupy a potential available niche (Heger \& Trepl 2003). Jackfruit that colonizes high biodiversity Atlantic Forest areas like TNP, at first excludes local plant species. In this case, the invasion success was determined by both the attributes of the invasive species and the susceptibility of the invaded ecosystem (Williamson 1996; Heger \& Trepl 2003). Additionally, disturbance and propagule pressure are factors that deserve attention because although they are confused, both factors play important roles in invasion of tropical forests (Edward \& Munishi 2009).

Jackfruit in his original habitat is rare, experiences a monsoon seasonally climate condition (Ayyappan \& Parthasarathy 1999; 
Table 5 - Secondary data extracted from phytossociological surveys in Atlantic Forest areas in Rio de Janeiro. $\mathrm{DBH}=$ minimum diameter adopted as inclusion criteria; $\mathrm{P}(\mathrm{ha})=$ size of original sampling area in hectares; $\mathrm{BA}=$ basal area $\left(\mathrm{m}^{2}\right)$ occupied by the species extrapolated to hectares; source $=$ reference from phytossociological survey.

\begin{tabular}{|c|c|c|c|c|}
\hline Species & DBH (cm) & P(ha) & BA $\left(\mathbf{m}^{2} h a^{-1}\right)$ & Source and place \\
\hline Artocarpus heterophyllus Lam. & 5 & 0.63 & 53.68 & This study* \\
\hline Artocarpus heterophyllus & 10 & 0.63 & 52.25 & This study* \\
\hline Metrodorea brevifolia Engl. & 10 & 1 & 4.13 & Silva \& Nascimento (2001) \\
\hline Paratecoma peroba (Record \& Mell) Kuhlm. & 10 & 1 & 1.26 & Tabuleiros do Norte - RJ \\
\hline $\begin{array}{l}\text { Pseudopiptadenia contorta (DC.) } \\
\text { G.P.Lewis \& M.P.Lima }\end{array}$ & 10 & 1 & 0.57 & \\
\hline Trichilia pseudostipularis (A. Juss.) C. DC. & 10 & 1 & 0.54 & \\
\hline Hyeronima alchorneoides Allemão & 10 & 0.6 & 4.26 & Moreno et al. 2003* \\
\hline Pseudopiptadenia contorta & 10 & 0.6 & 2.15 & Região do Imbé - RJ \\
\hline Rustia formosa (Cham. \& Schltdl. ex DC.) Klotzsc & ch 10 & 0.6 & 2.13 & \\
\hline Virola oleifera (Schott) A.C. Sm. & 10 & 0.6 & 2.10 & \\
\hline Actinostemon verticillatus (Klotzsch) Baill. & 10 & 0.6 & 1.60 & Moreno et al. 2003* \\
\hline Mabea fistulifera Mart. & 10 & 0.6 & 1.57 & Região do Imbé - RJ \\
\hline Maytenus commuta Reissek & 10 & 0.6 & 1.53 & \\
\hline Vochysia oppugnata (Velloso) Warm. & 10 & 0.6 & 1.47 & \\
\hline Cupania emarginata Cambess. & 10 & 0.4 & 4.81 & Rodrigues 2004* \\
\hline Ecclinusa ramiflora Mart. & 10 & 0.4 & 3.08 & REBIO União - RJ \\
\hline Ficus gomelleira Kunth \& C.D. Bouché & 10 & 0.4 & 2.93 & \\
\hline Pradosia kuhlmannii Toledo & 10 & 0.4 & 2.87 & \\
\hline Virola bicuhyba (Schott ex Spreng.) Warb. & 10 & 0.4 & 2.78 & \\
\hline Alchornea triplinervia (Spreng.) Müll. Arg. & 5 & 1 & 5.1 & Guedes-Bruni et al. 1997 \\
\hline Cabralea canjerana (Vell.) Mart. & 5 & 1 & 1.2 & Macaé de Cima - RJ \\
\hline Euterpe edulis Mart. & 5 & 1 & 1.9 & \\
\hline Mollinedia gilgiana Perkins & 5 & 1 & 1.5 & \\
\hline Myrcia pubipetala Miq. & 5 & 1 & 1.4 & \\
\hline Casearia obliqua Spreng. & 5 & 1 & 1.6 & Pessoa et al. 1997 \\
\hline Croton floribundus Spreng. & 5 & 1 & 2.6 & Macaé de Cima - RJ \\
\hline Euterpe edulis & 5 & 1 & 1.9 & \\
\hline Nephelea setosa (Kaulf.) R.M. Tryon & 5 & 1 & 1.2 & \\
\hline Tibouchina scrobiculata Cogn. & 5 & 1 & 3.9 & \\
\hline
\end{tabular}

* extrapolated values for hectares for comparison purposes only. The species were not observed in a continuous hectare.

Parthasarathy 1999) and exhibit synchronicity in fruiting processes (Khan 2004). Otherwise, in the Brazilian Atlantic Forest the absence of a marked dry season (Mattos et al. 1970) with water supply year-round a continued reproduction may be favored. In fact, it is expected that exotics grow faster and reproduce better in some invaded environments (Jakobs et al. 2004). It was also observed in TNP that jackfruits do not exhibit synchronicity in relation to the fruiting period, even considering the reproducing peak at summer. That is, different individuals, even neighbors, fruit at different times of the year. This is a common pattern in species 
of the family Moraceae (J.P.P. Carauta, personal comunication), as often observed in fig species (Romo 1996; Korine et al. 2000; Wendeln et al. 2000).

Asymmetric competition increases variation in growth rates between dominant and suppressed plants, its onset promotes size inequality, and this effect is heightened by time (Crawley 1997). Even with an uncertain elapsed time after species first establishment at each site, 150 years after introduction in TNP, population characteristics give to the jackfruit the same size hierarchy and a very similar population structure at different sites, showing that the biological invasion process is very similar in all sites. Jackfruit showed a population structure typical from shade-tolerant species, with many individuals in the first size class (JUVENILE 1). Together, the biology of a species and structures of diameters can provide valuable information about the successional process undergone by a subpopulation (White 1980). Different size classes may compose a stable population, and the proportions of these classes will vary in accordance to the abiotic and biotic factors those population individuals and their ancestors experienced historically (Sarukhán 1980; Hutchings 1986). Trees are more likely to survive if their neighbors die (Crawley 1997), so invasive species can supplant native species as the native die.

The barochory dispersal syndrome favors clumped spatial patterns as observed in these populations of jackfruit. That spatial pattern, especially of young and pre-reproductive individuals, has also been observed for native tree species of the Atlantic Forest such as Miconia cinnamomifolia (DC.) Naudim (Pereira 1998), Calophyllum brasiliense Camb. (Marques \& Joly 2000) and Caesalpinia echinata Lam. (Rodrigues et al. 2009). Pereira (1998) characterized M. cinnamomifolia as an initial secondary species, because it grows most densely in edge sites, although its density decreases as ecological succession progresses. In their native environment, jackfruits are considered typical of advanced successional stages (Khan 2004). In the Atlantic Forest, however, this species has occupied areas of secondary vegetation, from open areas to dense forests.

In the case of the jackfruits at TNP, both the local man-mediated introduction and the individual longevity explain the presence of this exotic per se. Although from some historically introduced individuals the species was capable of expanding its subpopulations, becoming invasive in areas of the Atlantic Forest underwent to some disturbance (e.g., park boundaries, roadsides). Considering that no differences were found among sites, based on basal area, subpopulation hierarchies, richness, biodiversity and canopy openness, it is probable that jackfruit is potentially an invasive species at TNP, even in places with small populations at present. All data showed that the Brazilian Atlantic Rainforest is a new habitat that allows the jackfruit to proliferate and dominate the plant community. So any place where jackfruit colonizes native forests in this ecological region can be a priority area for management, eradication being recommended at the first detection.

\section{Acknowledgments}

We are very grateful to ICMBio (Instituto Chico Mendes) from Tijuca National Park and UNIRIO (Universidade Federal do Estado do Rio de Janeiro) for logistical facilities; PETROBRAS by Financial support (Research funding to Programa Mata Atlântica/Pablo J.F.P. Rodrigues); Students that help us at fieldwork, two anonymous referees and to MSc.Talita Soares Reis, Dra. Giselda Durigan and Dr.Andre Mantovani Oliveira for suggestions on the manuscript.

\section{References}

Abreu, R.C.R. de \& Rodrigues, P.J.F.P. 2005. Estrutura de populações de jaqueiras, subsídios para manejo e conservação da Mata Atlântica. In: I Simpósio Brasileiro Sobre Espécies Exóticas Invasoras. Categoria 1: trabalhos científicos completos. Brasília. 14p.

Ayyappan, N. \& Parthasarathy, N. 1999. Biodiversity inventory of trees in a large-scale permanent plot of tropical evergreen forest at Varagaliar, Anamalais, Western Ghats, India. Biodiversity and Conservation 8: 1533-1554.

Atala, F.; Bandeira, C.M.; Martins, H.F.; Coimbra-Filho, A.F.; Chaves, C.M.; Tâmara, R.; Carauta, J.P.P.; Silveira, E.K.P. \& Vianna, M.C. 1966. Floresta da Tijuca. Centro de Conservação da Natureza, Rio de Janeiro. 152p.

Azevedo, D.A.; Moreira, L.O. \& Siqueira, D.S. 1999. Composition of extractable organic matter in aerosols from urban areas of Rio de Janeiro city, Brazil. Atmospheric Environment 33: 4987-5001.

Bagchi, S. 2007. Relationship between size hierarchy and density of trees in a tropical dry deciduous forest of western India. Journal of Vegetation Science 18: 389-394.

Bandeira, C.M. 1993. Parque Nacional da Tijuca. Markom Books, São Paulo. 170p.

Bhuyan, P.; Khan, M.L. \& Tripathi, R.S. 2003. Tree diversity and population structure in disturbed and human-impacted stands of tropical wet evergreen 
forest in Arunachal Pradesh, Eastern Himalayas, India. Biodiversity \& Conservation 12:1753-1773.

Bruna, E. M. \& W. J. Kress 2002. Habitat fragmentation and the demographic structure of an Amazonian understory herb (Heliconia acuminata). Conservation Biology 16: 1256-1266.

Carauta, J.P.P. \& Diaz, B.E. 2002. Figueiras no Brasil. Ed. UFRJ, Rio de Janeiro, RJ. 211p.

Cassey, P.; Blackburn, T.M.; Duncan, R.P. \& Chown, S.L. 2005. Concerning invasive species: reply to Brown \& Sax. Austral Ecology 30: 475-480.

Chaves, C.M.; Martins, H.F.; Carauta, J.P.P.; LannaSobrinho, J.P.; Vianna, M.C.; Silva, S.A.F. 1967. Arboreto carioca 3. Centro de Conservação da Natureza, Rio de Janeiro. 28p.

Chittibabu, C.V. \& Parthasarathy, N. 2000. Attenuated tree species diversity in human-impacted tropical evergreen forest sites at Kolli hills, Eastern Ghats, India. Biodiversity \& Conservation 9: 1493-1519.

Coelho-Netto, A.L.; Avelar, A.S.; Fernandes, M.C. \& Lacerda, W.A. 2007. Landslide susceptibility in a mountainous geoecosystem, Tijuca Massif, Rio de Janeiro: the role of morphometric subdivision of the terrain. Geomorphology 87: 120-131.

Conti, V.M.; Iwamoto S.; Hidalgo, Almeida, T.M.H. \& Pereira, T.S. 2008. Revisão dos limites do Jardim Botânico do Rio de Janeiro, Brasil. Rodriguésia 59: 603-607.

Crane, J.H.; Balerdi, C.F. \& Campbell, R.J. 2002. The Jackfruit (Artocarpus heterophyllus Lam.) in Florida. University of Florida IFAS Extension. Fact Sheet HS-882.

Crawley, M.J. 1997. Plant ecology. $2^{\text {nd }}$ ed. Blackwell Science, Cambridge. 496p.

Cronk, Q.C.B. \& Fuller, J.L. 1995. Plant invaders. Chapman \& Hall, London. 241p.

Cunha, A.A.; Vieira, M.V. \& Grelle, C.E.V. 2006. Preliminary observations on habitat, support use and diet in two non-native primates in an urban Atlantic forest fragment: The capuchin monkey (Cebus sp.) and the common marmoset (Callithrix jacchus) in the Tijuca forest, Rio de Janeiro. Urban Ecosystems 9: 351-359.

Damgaard, C. \& Weiner, J. 2000. Describing inequality in plant size of fecundity. Ecology 81:1139-1142.

Davis, M.A.; Grime, J.P. \& Thompson, K. 2000. Fluctuating resources in plant communities: a general theory of invisibility. Journal of Ecology 88:528-534.

Dawson, W., Burslein, D.F.R.P. \& Hulme, P.E. 2009. Factors explaining alien plant invasion success in a tropical ecosystem differ at each stage of invasion. Journal of Ecology 97: 657-665.

Dean, W. 2002. A ferro e fogo: a história e a devastação da Mata Atlântica brasileira. Cia. das Letras, São Paulo. 484p.
Dixon, P.M.; Weiner, J.; Mitchell-Olds, T. \& Woodley, R. 1987. Bootstrapping the Gini coefficient of inequality. Ecology 68:1548-1551.

Edward, E. \& Munishi, P. K. T. (2009). Relative roles of disturbance and propagule pressure on the invasion of humid tropical forest by Cordia alliodora (Boraginaceae) in Tanzania. Biotropica 41: 171-178.

Ferrão, J.E.M. 1993. A aventura das plantas e os descobrimentos portugueses. $2^{\text {a }}$ ed. Instituto de Investigação Científica Tropical, Lisboa. 241p.

Fine, P.V.A. 2002. The invasibility of tropical forests by exotic plants. Journal of Tropical Ecology 18: 687-705.

Guedes-Bruni, R.R.; Pessoa, S.V.A. \& Kurtz, B.C. 1997. Florística e estrutura do componente arbustivo-arbóreo de um trecho preservado de floresta montana na Reserva Ecológica de Macaé de Cima. In: Lima, H.C. \& Guedes-Bruni, R.R. (eds.). Serra de Macaé de Cima: Diversidade Florística e Conservação em Mata Atlântica. Rio de Janeiro. Pp. 127-145.

Heger, T. \& Trepl, L. 2003. Predicting biological invasions. Biological Invasions 5: 313-321.

Hutchings, M.J. 1986. The structure of plant populations. In: M.J.Crawley (Eds.), Plant Ecology (pp 97-136). Blackwell, Oxford.

IBAMA. 2004. Proposta de ampliação e correção de limites do Parque Nacional da Tijuca. Gestão compartilhada IBAMA e Prefeitura da Cidade do Rio de Janeiro.

IBGE 2006. Contagem da população. In: População. Instituto Brasileiro de Geografia e Estatística. Avaiable in <http://www.ibge.gov.br/home/estatistica/ populacao/contagem2007/RJ.pdf>. Accessed 15 Aug 2007.

Jakobs, G.; Weber, E. \& Edwards, P.J. 2004. Introduced plants of the invasive Solidago gigantean (Asteraceae) are larger and grow denser than conspecifics in the native range. Diversity \& Distributions 10: 11-19.

Khan, M.L. 2004. Effects of seed mass on seedling success in Artocarpus heterophyllus Lam., a tropical tree species of north-east India. Acta Oecologica 25: 103-110.

Keane, R.M. \& Crawley, M.J. 2002. Exotic plant invasions and the enemy release hypothesis. Trends in Ecology \& Evolution 17: 164-170.

Korine, C.; Kalko, E.K.V. \& Herre, E.A. 2000. Fruit characteristics and factors affecting fruit removal in a Panamanian community of strangler figs. Oecologia 123: 560-568.

Kourtev, P.S.; Huang, W.Z. \& Ehrenfeld, J.G. 1999. Differences in earthworm densities and nitrogen dynamics in soils under exotic and native plant species. Biological Invasions 1: 237-245.

Krebs, C.J. 1989. Ecological methodology. Harper \& Row, New York. 
Marques, M.C.M. \& Joly, C.A. 2000. Estrutura e dinâmica de uma população de Calophyllum brasiliense Camb. em floresta higrófila do sudeste do Brasil. Revista Brasileira de Botânica 23: 107-112.

Mattos, C.C.L.V.; Mattos, M.D.L.V. \& Laroche, R.C. 1970. Aspectos do clima e da flora do Parque Nacional da Tijuca. Brasil Florestal: 5-12.

McCune, B. \& Mefford, M. J. 1999. PC-ORD. Multivariate Analysis of Ecological Data. Version 5.19 beta MjM Software, Gleneden Beach.

McKinney, M.L. \& Lockwood, J.L. 1999. Biotic homogenization: a few winners replacing many losers in the next mass extinction. Trends in Ecology \& Evolution 14: 450-453.

Moreno, M.R.; Nascimento, M.T. \& Kurtz, B.C. 2003. Estrutura e composição florística do estrato arbóreo em duas zonas altitudinais na Mata Atlântica de encosta da região do Imbé, RJ. Acta Botanica Brasilica 17: 371-386.

Müeller-Dumbois, D. \& Ellenberg, H. 1974. Aims and methods of vegetation ecology. John Wiley \& Sons, New York. 570p.

Oliveira, R.R. 2007. “Terras cançadas e mattas estragadas”: uma pequena história ambiental das chuvas e florestas do Rio de Janeiro. In: Gari, V.R.; Schlee, M.B.; Andrade, R. \& Dias, M.A. (orgs.). Águas urbanas: a regeneração ambiental como campo disciplinar integrado. Vol. 1. FAPERJ/PROARQ-FAUUFRJ/ Minister Ed., Rio de Janeiro. Pp. 57-77.

Oliveira, R.R.; Zaú, A.S.; Lima, D.F.; Vianna, M.C.; Socré, D.O. \& Sampaio, P.D. 2005. Significado ecológico da orientação de encostas no maciço da Tijuca, Rio de Janeiro. Oecologia Brasiliensis 1: 523-541.

Parthasarathy, N. 1999. Tree diversity and distribution in undisturbed and human-impacted sites of tropical wet evergreen forest in southern Western Ghats, India. Biodiversity and Conservation 8: 1365-1381.

Pereira, T.S. 1998. Ecologia de Miconia cinnamomifolia (DC.) Naudim, Jacatirão na sucessão secundária da mata atlântica. Tese de doutorado. Universidade de São Paulo, São Paulo. 149p.

Pessoa, S.V.A.; Guedes-Bruni, R.R. \& Kurtz, B.C. 1997. Composição florística e estrutura do componente arbustivo-arbóreo de um trecho secundário de floresta montana na Reserva Ecológica de Macaé de Cima. In: Lima, H.C. \& Guedes-Bruni, R.R. (eds.). Serra de Macaé de Cima: diversidade florística e conservação em Mata Atlântica. Rio de Janeiro. Pp 147-167.

Pimentel, D.; McNair, S.; Janecka, J.; Wightman, J.; Simmonds, C.; O’Connel, C.; Wong, E.; Russel, L.; Zern, J.; Aquino, T. \& Tsomondo, T. 2001. Economic and environmental threats of alien plant, and microbe invasions. Agricultural Ecosystems \& Environment 84: 1-20.

Pivello, V.R.; Shida, C.N. \& Meirelles, S.T. 1999. Alien grasses in Brazilian savannas: a threat to the biodiversity. Biodiversity \& Conservation 8: 1281-1294.
Regent 2003. WinSCANOPY for hemispherical image analysis - Manual. Regent Instruments Inc. Pp 104.

Richardson, D.M.; Pysek, P.; Rejmánek, M.; Barbour, M.G.; Panetta, F.D. \& West, C.J. 2000. Naturalization and invasion of alien plants: concepts and definitions. Diversity \& Distributions 6: 93-107.

Rodrigues, P.J.F.P. 2004. A vegetação da Reserva Biológica União e os efeitos de borda na Mata Atlântica. Tese de Doutorado. Universidade Estadual do Norte Fluminense, Campos dos Goytacazes.

Rodrigues, P.J.F.P.; Abreu, R.C.R.; Barcellos, E.M.B.; Lima, H.C. \& Scarano, F.R. 2009. Population structure and one-year dynamics of the endangered tropical tree species Caesalpinia echinata Lam. (Brazilian red-wood): the potential importance of small fragments for conservation. Rodriguésia 60: 211-220.

Romo, M.C. 1996. Seasonal variation in fruit consumption and seed dispersal by canopy bats (Artibeus spp.) in a lowland forest in Peru. Vida Silvestre Neotropical 5: 110-119.

Rouvinen, S. \& Kuuluvainen, T. 2005. Tree diameter distributions in natural and managed old Pinus sylvestris-dominated forests. Forest Ecology and Management 208: 45-61.

Sadras, V. \& Bongiovanni, R. 2004. Use Lorenz Curves and Gini coefficients to asses yield inequality within paddocks. Field Crop Research 90: 303-310.

Santos, F.A.M. 1996. Wingini: programa para cálculo do coeficiente de Gini. Versão 1.0. Departamento de Botânica, Universidade Estadual de Campinas, Campinas.

Sarukhán, J. 1980. Demography problems in tropical systems. In: Solbrig, O. T. (ed.). Demography and evolution in plant populations. Blackwell, Oxford. Pp. 161-188.

Sax, D.F. \& Brown, J.H. 2000. The Paradox of invasion. Global Ecology \& Biogeography 9: 363-372.

Scariot, A. 2001. Weedy and secondary palm species in central Amazonian forest fragments. Acta Botanica Brasilica 15: 271-280.

Silva, G.C. \& Nascimento, M.T. 2001. Fitossociologia de um remanescente de mata sobre tabuleiros no norte do estado do Rio de Janeiro (Mata do Carvão). Revista Brasileira de Botânica 24: 51-62.

Simberloff, D. 2003. Confronting introduced species: a form of xenophobia? Biological Invasions 5:179-192.

Sodhi, N.S.; Peh, K.S-H.; Lee, T.M.; Turner, I.M.; Tan, H.T.W.; Prawiradilaga, D.M. \& Darjono 2003. Artificial nest and seed predation experiments on tropical Southeast Asian islands. Biodiversity \& Conservation 12: 2415-2433.

Solbrig, O.T. \& Solbrig, D.J. 1984. Size inequalities and fitness in plant populations. In: Dawkins, R. \& Ridley, M. (eds.). Oxford surveys in evolutionary biology. Vol. 1. Oxford University Press, Oxford. Pp. 141-159. 
Souza, A.F. \& Martins, F.R. 2002. Spatial distribution of an undergrowth palm in fragments of the Brazilian Atlantic Forest. Plant Ecology 164: 141-155.

Stohlgren, T.J.; Otsuki, Y.; Villa, C.A.; Lee, M. \& Belnap, J. 2001. Patterns of plant invasions: a case example in native species hotspots and rare habitats. Biological Invasions 3: 37-50.

Stohlgren, T.J.; Binkley, D.; Chong, G.W.; Kalkhan, M.A.; Schell, L.D.; Bull, K.A.; Otsuki, Y.; Newman, G.; Bashkin, M. \& Son, Y. 1999. Exotic plant invade hot spots of native plant diversity. Ecological Monographs 69: 25-46.

Weiner, J. \& Solbrig, O.T. 1984. The meaning and measurement of size hierarchies in plant populations. Oecologia 61: 334-336.

Weiner, J. 1985. Size hierarchies in experimental populations of annual plants. Ecology 66: 743-752.
Weiner, J. 1986. How competition for light and nutrients affects size variability in Ipomea tricolor populations. Ecology 67: 1425-1427.

Wendeln, M.C.; Runkle, J.R. \& Kalko, E.K.V. 2000. Nutritional values of 14 fig species and bat feeding preferences in Panama. Biotropica 32:489-501.

White, J. 1980. Demographic factors in populations of plants. In: Solbrig, O.T. (ed.). Demography and evolution in plant populations. Blackwell Science Publications, Oxford. Pp. 21-48.

Williamson, M. 1996. Biological invasions. Chapman \& Hall. 244p.

Zavaleta, E.S.; Hobbs, R.J. \& Mooney, H.A. 2001. Viewing invasive species removal in a wholeecosystem context. Trends in Ecology and Evolution 16: 454-459. 